\title{
Analyzing Students' Needs for Essay Writing Course at University
}

\author{
M. Aries Taufiq ${ }^{1, *}$ M. Zaim ${ }^{1,}$ Yasnur Asri ${ }^{1}$ \\ ${ }^{1}$ Ilmu Keguruan Bahasa, Fakultas Bahasa dan Seni, Universitas Negeri Padang, Padang, Indonesia \\ "Corresponding author. Email: ariespertama@gmail.com
}

\begin{abstract}
As a part of research and development, this research aimed to identify students' need in Essay Writing course at higher education. This descriptive research was conducted by administering a needs analysis questionnaire to the fifth semester students as well as by conducting an interview to the Writing lecturer and the head of English Education Department. The questionnaire and interview guideline were elaborated from the needs analysis indicators including the purpose of learning Essay writing, the methodology, available sources, students' characteristics, and the setting of the course. The results revealed that (1) Essay Writing course was dominantly delivered by having presentation and discussion; (2) Students were motivated to learn through various techniques and strategies providing more opportunities to practice writing, to participate in tasks to develop their writing ability, to access various learning sources and examples, and to get guidance from the lecturer to revise their writing; and (3) Essay Writing course needed to facilitate learning which assisted students to take control and become active participants in their own learning. Overall, this research implied the need of an appropriate learning model which provided an insight and guidance to fulfill the needs in order to enhance students' ability in writing an essay.
\end{abstract}

Keywords: Needs Analysis, Essay Writing, University Students, Learning Model.

\section{INTRODUCTION}

As an institution to produce intellectuals, higher education conduct writing activities as an integrated part in the entire teaching and learning process. With this writing activity, students are expected to have a broader insight about the topics they write about. Writing in college requires several necessary aspects in terms of language, content and writing techniques. In addition to the practice, students must also have knowledge of the material to be written. For these reasons, writing becomes one of essential skills students have to master at university.

However, writing is often found to be challenging for students. Writing is not an easy task because conveying written message through written texts is not simple [1], [2]. It takes study and practice to develop writing skill. Similar to this, Nunan [3] comments that writing is a complex cognitive activity in which a writer is demanded to demonstrate continual competences, such as ideas, sentence format, vocabulary, spelling as well as the ability to arrange and combine ideas, thoughts and information into a coherence and cohesive paragraph. As a consequence, writing is considered a problematic language skill, even for native speakers.

Various studies revealed that several factors cause a lack of student writing skills. One of the factors that influences these conditions was the use of inappropriate learning approaches [4]-[6]. Some lecturers were unable to optimize their learning so that students' writing abilities were still below the expected standard [7]. Some students told that they had never been taught to write well before entering college so that they found it difficult to express their ideas and ideas into the written form [8]. Meanwhile, based on the preliminary research conducted at one of higher institutions, the students asserted that the learning approach utilized by the lecturers in the writing class was quite boring. The students commented that they need more various and challenging learning approach so that learning would be more interesting and their learning motivation increased. At last, it was found that there was no adequate feedback to the students' writing from the lecturer.

Considering the problems encountered by students, the demand to find appropriate learning models that can fulfil the target of learning and the students' expectation 
in the writing class is required. The teachers and lecturers need to develop a learning model which can make the learning process more effective and meaningful. This is supported by Harmer [9] arguing that teachers should find the appropriate models and methodological beliefs to lead the teaching practice. In addition, if there are appropriate methods and models, it will be possible to change the students' attitude in writing that writing can be an interesting, easy and enjoyable activity. Based on the explanation above, it is suggested to develop an appropriate model to teach writing in a language classroom.

Needs analysis is the first stage in developing a learning model. It refers to a series of activities carried out to identify and search for information related to initial needs before making improvements or developing a learning product. As asserted by many researchers, needs analysis or identifying students' needs, is the crucial initial step in developing an appropriate learning model [10]-[13]. Needs analysis is perceived as the most appropriate method as it can tell a lot about the nature and content of the students' target language needs [14] p. 71 .

Generally, in this stage, a course designer has to gather information about students' present and target situations [10], through present situation analysis (PSA) and target situation analysis (TSA). Hutchinson and Waters [15] developed TSA and PSA into a more manageable framework, adopted in the present research. They identified three components of target needs: necessity (needs identified by the requirements of target situation), lacks (the necessary proficiency for the target situation compared to what the students already know), and wants (what the students desire to learn).

Whereas, Hutchinson and Waters in [16] p. 24-25 divide needs into target needs and learning needs. Target needs refer to what the learner needs to know in order to function in the target situation, what they know already, and what they need to know. Target needs make sure that the course contains relevant and useful things to learn. It is more useful to look at the target situation in terms of necessities, lacks, and wants. Necessities refer to what the learner has to know in order to function effectively in the target situation. Lacks refer to the gap between the target proficiency and the existing proficiency. On the other hand, wants refer to what the learner wishes to learn.

The main purpose of this study was to investigate the appropriate learning for Essay Writing course at university. To reach this purpose, the needs analysis conducted in this study aimed to identify problems faced students and lecturers in Essay Writing course, the students' expectation in Essay Writing Course.

\section{METHODS}

This study utilized a descriptive qualitative method. 70 students, one writing lecturer, and the the head of English Department were involved in this study. The intended data were collected through a questionnaire and an interview guideline which were designed following the needs analysis indicators from Hutchinson and Waters [15]. The questionnaire was distributed to the fifth semester students while the interview was conducted to the writing lecturer and the head of English Department. Data from the questionnaire were then analyzed by the formula from Sudjana and Ibrahim [17] and classified into low, medium and high. Then, data from the interview were used to support the results from the questionnaire.

\section{RESULTS AND DISCUSSIONS}

Essay writing course at higher education is designed to enable students to write academic essay systematically, particularly writing several kinds of essay such as cause-effect, comparison-contrast, argumentative, and chronological order. Analyzing needs means the analysis of students' present situation, students' ability and difficulties to Essay Writing course, students' needs, the existing materials, the objectives of the course, as well as the identification of the result of analysis.

Data obtained for analyzing the needs in this study were grouped into (a) course objectives, (b) learning methods, (c) available sources, (d) students' characteristics, and (e) setting of the course. Findings of this study are discussed below.

\subsection{Learning Objectives}

The result of learning objectives is displayed in Table 1. 
Table 1. Learning Objectives

\begin{tabular}{|c|l|c|c|}
\hline No & $\begin{array}{c}\text { The objective of } \\
\text { taking essay writing } \\
\text { course }\end{array}$ & Percentage & Category \\
\hline 1 & $\begin{array}{l}\text { To help students write } \\
\text { an English essay well. }\end{array}$ & $93.9 \%$ & High \\
\hline 2 & $\begin{array}{l}\text { To help students write } \\
\text { other English texts } \\
\text { well. }\end{array}$ & $90.4 \%$ & High \\
\hline 3 & $\begin{array}{l}\text { To help students write } \\
\text { their final task/ thesis. }\end{array}$ & $100 \%$ & High \\
\hline
\end{tabular}

Table 1 demonstrated that students took Essay Writing course for three reasons. The first reason was that they took Essay Writing course to help them write an English essay well. Second, the students took Essay Writing course to be able to write other English texts. At last, Essay Writing course was expected to help the students write their final task (thesis).

In addition, the result of the interview revealed that students took Essay Writing course to enable them to develop and produce several kinds of essays such as cause - effect, comparison - contrast, argumentative, and chronological order. It was hoped that this course assisted students to quote information from various sources and to write abstracts and references.

\subsection{Learning Methods}

The finding on the learning methods is demonstrated in Table 2.

Table 2. Learning Methods

\begin{tabular}{|c|l|c|c|}
\hline No & \multicolumn{1}{|c|}{$\begin{array}{c}\text { Way the Students } \\
\text { Learn }\end{array}$} & Percentage & Categories \\
\hline 1 & $\begin{array}{l}\text { Essay Writing is taught } \\
\text { by giving examples of a } \\
\text { good essay. }\end{array}$ & $95.7 \%$ & High \\
\hline 2 & $\begin{array}{l}\text { Essay Writing is taught } \\
\text { by having group } \\
\text { discussion. }\end{array}$ & $73.2 \%$ & High \\
\hline 3 & $\begin{array}{l}\text { Essay Writing is taught } \\
\text { by practicing the } \\
\text { writing techniques. }\end{array}$ & $94.6 \%$ & High \\
\hline 4 & $\begin{array}{l}\text { Essay Writing is taught } \\
\text { by providing detailed } \\
\text { guidelines. }\end{array}$ & $95.4 \%$ & High \\
\hline 5 & $\begin{array}{l}\text { Students are given } \\
\text { bigger role in learning } \\
\text { process. }\end{array}$ & $88.9 \%$ & High \\
\hline 6 & $\begin{array}{l}\text { Essay Writing is } \\
\text { centered to solve } \\
\text { problems. }\end{array}$ & $85.7 \%$ & High \\
\hline 7 & $\begin{array}{l}\text { Essay Writing learning } \\
\text { produce product and } \\
\text { can be presented }\end{array}$ & $82.7 \%$ & High \\
\hline
\end{tabular}

\begin{tabular}{|c|l|c|c|}
\hline 8 & $\begin{array}{l}\text { Practice of essay } \\
\text { writing is given bigger } \\
\text { proportion in the } \\
\text { classroom. }\end{array}$ & $94.8 \%$ & High \\
\hline
\end{tabular}

This point was intended to identify a methodology that appeals to the students and sort of techniques likely to alienate the students in learning Essay Writing course. Data in this study showed that there were four methods the students wished to be practiced in the Essay Writing course. The students expected to attend the Essay Writing course which provided them examples of a good essay. They agreed that Essay Writing should be taught by providing detailed guidelines of writing an essay. The students also wished to learn by directly practicing the writing techniques. Moreover, they stated that Essay Writing course should be taught by having group discussions so that the students' role in learning increased. In addition, the focus of this course would be problem solving and at the end of the learning process, the writing product could be presented in the classroom.

The result of the questionnaire was strengthened by the statement given by the head of English Department and the writing lecturer. Based on the interview, they commented that the students preferred to learn through group works and peer-review. The writing lecturer revealed that sometimes the students did not prefer to have discussion session in the classroom. They wished to learn by having more examples of essays; then, they work together by getting the guidance from the lecturer.

Based on the data above, it is known that group works and lecturer's feedback were the main methods the students wished to have in the Essay Writing class. They learned better when they could discuss the ideas for the essay with their friends and the lecturer guided them during the writing process. At the end, the lecturer provided feedback for the improvement of their essay.

\subsection{Available Sources}

The finding on the learning methods is demonstrated in Table 3.

Table 3. Available Learning Sources

\begin{tabular}{|c|l|c|c|}
\hline No & \multicolumn{1}{|c|}{$\begin{array}{c}\text { Available Learning } \\
\text { Sources }\end{array}$} & Percentage & Categories \\
\hline 1 & $\begin{array}{l}\text { Generally, the lecturers } \\
\text { possess good } \\
\text { qualifications in } \\
\text { writing. }\end{array}$ & $92.9 \%$ & High \\
\hline 2 & $\begin{array}{l}\text { The materials are } \\
\text { exclusively designed } \\
\text { for Essay Writing } \\
\text { subject. }\end{array}$ & $86.1 \%$ & High \\
\hline 3 & The materials should be & $87.9 \%$ & High \\
\hline
\end{tabular}




\begin{tabular}{|c|l|c|c|}
\hline & $\begin{array}{l}\text { designed from various } \\
\text { sources. }\end{array}$ & High \\
\hline 4 & $\begin{array}{l}\text { The topics of Essay } \\
\text { Writing are taken from } \\
\text { problem in real } \\
\text { situation. }\end{array}$ & $92.9 \%$ & High \\
\hline 5 & $\begin{array}{l}\text { The sources are } \\
\text { provided by the } \\
\text { lecturer. }\end{array}$ & $80.4 \%$ & High \\
\hline 6 & $\begin{array}{l}\text { The lecturer gives the } \\
\text { sample essays the } \\
\text { students want to write. }\end{array}$ & $88.6 \%$ & High \\
\hline 7 & $\begin{array}{l}\text { The lecturer presents } \\
\text { videos and pictures } \\
\text { when delivering the } \\
\text { materials. }\end{array}$ & $78.6 \%$ & High \\
\hline 8 & $\begin{array}{l}\text { The lecturer supplies } \\
\text { digital learning sources } \\
\text { for Essay Writing } \\
\text { subject. }\end{array}$ & $80.7 \%$ & \\
\hline
\end{tabular}

This point was intended to identify the learning sources available for the students in learning Essay Writing course. There were eleven statements included in this part related to the qualified writing lecturers, the materials, and sources provided for the students in Essay Writing course. The learning sources in this study refer to the lecturers and learning materials.

The results of this study found that there was sufficient number of lecturers who possessed good qualifications in writing subjects as the result of the students' response showed High classifications. Related to the materials, the result of this study also revealed that the students needed an Essay Writing class in which the lecturer presented various media such as videos and pictures when delivering the materials and provided the sample essay the students want to write. In other words, the materials prepared for this subject were compiled from various sources, not from one single textbook only, and the lecturer should supply several digital learning sources for Essay Writing subject when possible.

Another point obtained from the questionnaire was that students wished to get materials that were exclusively designed for Essay Writing subject. Finally, at the end of the writing process, the students wished to revise their writing together in the classroom so that they would know their mistakes clearly and how to revise it. By having a discussion on revising their writing, the students would also get more knowledge of writing a good essay.

Furthermore, the interview results indicated that learning sources provided at English Department of
IAIN Bukittinggi were still quite limited. The writing lecturer asserted that she only focused on one particular book (Academic Writing by Oshima) as the main source. However, sometimes she downloaded some materials from the internet, such as the sample texts. This was supported by the statement from the head of English Department saying that sometimes the lecturer used internet based materials as additional learning sources.

\subsection{Students characteristics}

The finding on the students characteristics is demonstrated in Table 4.

Table 4. Students Characteristics

\begin{tabular}{|c|l|c|c|}
\hline No & \multicolumn{1}{|c|}{$\begin{array}{c}\text { Students } \\
\text { Characteristics }\end{array}$} & Percentage & Categories \\
\hline \multicolumn{2}{|c|}{ Students' Ability } \\
\hline $1 \quad$ Basic level & $76.1 \%$ & High \\
\hline \multicolumn{2}{|c|}{ Learning Interests } & High \\
\hline 2 & $\begin{array}{l}\text { The course focuses } \\
\text { on grammar. }\end{array}$ & $85.4 \%$ & High \\
\hline 3 & $\begin{array}{l}\text { The course focuses } \\
\text { on essay writing } \\
\text { process. }\end{array}$ & $84.6 \%$ & \\
\hline
\end{tabular}

This point was intended to identify the students' writing ability as well as their interests in learning essay writing. In term of the ability, the data of this study presented that the students generally possessed basic and intermediate level in writing. To support this, the result of the interview conducted with the writing lecturer revealed that most of the students were still at the basic level of writing ability. This was due to the fact that they were unable to produce a good paragraph; as a result, it was difficult for them to write an essay.

In addition, data from the questionnaire also revealed that the students wished to have the Essay Writing course which emphasized on the grammar and essay writing process. In line with this result, based on the interview conducted with the lecturer, she asserted that there were four main aspects the students were still incapable of; they were grammar, vocabulary, arranging ideas, and cohesion. The writing lecturer admitted that those problems appeared because of the influence of their first language. Besides, as mentioned earlier, the students got problems in writing an essay because they had not overcome writing a paragraph.

Based on data from the questionnaire and interview, it could be concluded that the students need a learning model which assist and provide them the opportunity to explore their writing ability, not only for the writing aspects but also the language aspects, such as grammar. 


\subsection{Setting of the Course}

The finding on the students' characteristics is demonstrated in Table 5.

Table 5. Setting of the Course

\begin{tabular}{|c|l|c|c|}
\hline No & \multicolumn{1}{|c|}{$\begin{array}{c}\text { Students } \\
\text { Characteristics }\end{array}$} & Percentage & Categories \\
\hline \multicolumn{2}{|c|}{ Place } & High \\
\hline 1 & $\begin{array}{l}\text { The class is } \\
\text { comfortable and the } \\
\text { environment supports } \\
\text { students to master } \\
\text { essay writing skills. }\end{array}$ & $84.3 \%$ & High \\
\hline Time & $\begin{array}{l}\text { More than once a } \\
\text { week (2 credits each) }\end{array}$ & $85.4 \%$ & High \\
\hline 3 & $\begin{array}{l}\text { Taught for more than } \\
\text { one semester }\end{array}$ & $87.9 \%$ & \\
\hline
\end{tabular}

This point was intended to identify the best setting where the course takes place. This study revealed that most of the students agreed that the class was comfortable and facilitated them to master the writing skills. This was supported by the information obtained from the writing lecturer during the interview. She stated that the classroom was comfortable and could accommodate all students. In addition to the classroom, she added that other facilities were also good and the campus continued to improve the facilities. Unfortunately, the environment did not really support the students to explore their English skills since many students were still less motivated to use English outside the classroom.

The table shows that most of the students wished to have the Essay Writing class for more than once a week (2 credits each meeting). Moreover, the students preferred to attend this course for more than one semester. In line with the result of the questionnaire, the interview result also revealed that both the head of English Department and the lecturer agreed that the time provided to teach Essay Writing was insufficient. The head of English Department asserted that Essay Writing should be taught in 4 credits every meeting for 16 meetings. This was supported the statement from the lecturer saying that 2 credits for every week was not sufficient to learn writing. Essay Writing course required much time due to the writing process the students should follow. She suggested having Essay Writing in 4 credits each week.

Having discussed previously, it was obvious that writing skills possesses a vital role for students at higher education. This fact is based on the fact that the university always requires students to be able to write well. Besides, the students were fully aware that writing skills are needed in finding work in the future [18]. Besides, writing skills are believed to have a role in improving students' literate abilities in writing [19].

Based on the data from questionnaire and interview above, it is indicated that the time is a crucial aspect in Essay Writing course. The lecturer needed to check the students' essay and the available time was not sufficient for the lecturer to do that. The lecturer admitted that only few students could have the chance to present their essay in order to have the review from their friends and the lecturer. In addition, this study also found that there was a demand to increase students' participation in learning process. It should be centered to problem solving in which the students would be expected to produce a writing product which would be presented in front of the classroom. Lastly, the topic of Essay Writing should be taken from problems in real situation. In other words, the expected learning model should facilitate the opportunity for students to practice writing an essay more often and should create a learning process which built the students' self-directed learning.

The results of questionnaire and interview with lecturers and the head of English Department resulted in three main themes: problems, needs, and solution viewing from the students' side, lecturers' side, and the materials. It was discovered that the students needed a new atmosphere in Essay Writing course, a learning process which provided them to get more opportunities to write and to build their self-directed learning during the process. It was also revealed that Essay Writing course should activate students' critical thinking so that students become more effective problem-solvers and self-directed learners while the lecturers become a tutor or cognitive coach who models inquiry strategies, guides exploration and help students clarify and pursue their research questions.

\section{CONCLUSIONS}

This study was the needs analysis stage in developing an effective learning model for Essay Writing course. Through this needs analysis process, the obstacles and expectations for having an effective learning process could be mapped. Several points found in this study were that the students expected to learn to write essay through various techniques and strategies; a learning which allowed them to practice writing more often and to revise their writing with guidance from the 
lecturer. They preferred to learn from various learning sources and examples as well as to participate in tasks (peer reviewing) to develop their writing ability so that their learning autonomy could be enhanced. In addition, the students wished to get guidance from the lecturer to revise their writing. It was also expected that there would be more available time to practice writing and to get feedback from the lecturer. In short, Essay Writing course needs to facilitate learning by assisting students to take control and become active participants in their own learning. For this reason, a new and innovative learning model was required to create a more effective and efficient learning process, a new learning model that could enhance students' understanding and insights about writing an essay.

\section{ACKNOWLEDGMENTS}

The authors are grateful for the financial support provided by The Ministry of Education, Culture, Research and Technology of The Republic of Indonesia through doctoral dissertation research grant.

\section{REFERENCES}

[1] A. Oshima, A. \& Hogue, Writing Academic English. New York: Longman, 1998.

[2] D. \& R. L. A. Zemach, Academic Writing from Paragraph to Essay. Oxford: McMillan, 2005.

[3] D. Nunan, Practical English Language Teaching. Singapore: McGraw Hill Company, 2003.

[4] R. Ivanic and M. R. Lea, "New Contexts, New Challenges: The Teaching of Writing in UK Higher Education," in Teaching Academic Writing in UK Higher education: Theories, Practices and Models, Ganobcsik-., London: Macmillan Publishing Company, 2006.

[5] Babalola and H. A. Litinin, "Effects of Processgenre Based Approach on the Written English Performance of Computer Science Students in a Nigerian Polytechnic," J. Educ. Pract., vol. 3, no. 6, pp. 1-7, 2012.

[6] T. K. Akinwamide, "The Influence of Process Approach in ESL Students Performance in Essay Writing," J. English Lang. Teach., vol. 5, pp. 16-29, 2012.

[7] N. Heffernan, "An Integrated Approach to Teaching Academic Writing," Asian EFL J., vol. 8, no. 3, pp. 249-258, 2006.

[8] C. Y. Keong and I. H. Mussa, "Academic Writing Difficulties of Iraqi Postgraduate Students in Malaysia," Int. Joural Educ. Res., vol. 3, no. 6, pp. 25-34, 2015.

[9] J. Harmer, How to Teach Writing. London: Longman, 2004.

[10] T. Dudley-Evans and M. St. Johan, Developments in ESP: A Multidisciplinary Approach. Cambridge: Cambridge University Press, 1998.

[11] K. Hyland, English for Academic Purposes: An Advanced Resource Book. London: Routledge, 2006.

[12] D. Kavaliauskiene, G., and Uzpaliene, "Ongoing needs analysis as a factor to language learning," J. Lang. Learn., vol. 1, no. 1, pp. 411,2003

[13] R. West, "Needs analysis in language teaching," Lang. Teach., vol. 27, no. 1, pp. 1-19, 1994.

[14] T. Hutchinson, "Making materials work in the ESP classroom," in ESP in the Classroom: Practice and Evaluation, Oxford: Modern English Publication, 1988, pp. 71-75.

[15] A. Hutchinson, T., \& Waters, English for Specific Purposes. Cambridge: Cambridge University Press, 1987.

[16] J. Nation, I. S. P., \& Macalister, Language Curriculum Design. New York: Routledge, 2010.

[17] N. dan I. Sudjana, Penelitian dan Penilaian Pendidikan. Bandung: Sinar Baru Algensindo, 2007.

[18] A. S. E. Mohammed and H. S. M. Nur, "Needs Analysis in English for Academic Purposes: The Case of Teaching Assistants at the University of Khartoum," $H O W$, vol. 25, no. 2, pp. 49-68, 2018.

[19] S. Sabarun, "Needs Analysis on Developing EFL Paragraph Writing Materials at Kalimantan L2 learners," English Lang. Teach., vol. 12, no. 1, pp. 186-193, 2019. 